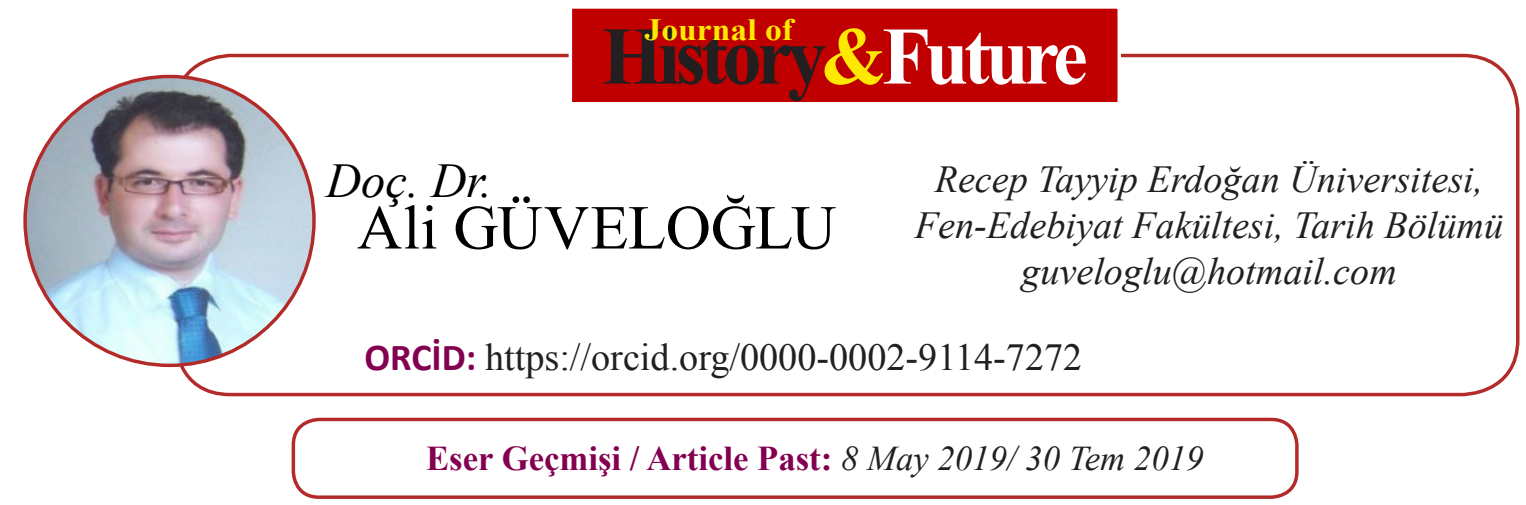

Araştırma Makalesi DOI: http://dx.doi.org/10.21551/jhf.561887 Research Paper

Orjinal Makale / Orginal Paper

\title{
Antik Çağ’ın Damak Tadı Düşkünü Yazarları
}

\author{
The Taste Follewer Writers of Ancient History
}

\section{$\ddot{O} \mathbf{z}$}

Hellen ve Roma toplumlarında damak tadı ve lezzet arayışlarının incelendiği bu çalışmanın amacı adı geçen uygarlıkların yeme-içme alışkanlıklarındaki eğilimleri incelemek ve eğer varsa bu eğilimleri belirleyen kişileri ve bunların toplum içindeki statülerini belirlemektir. Konuyla ilgili bilgiler M.Ö. III. yüzyıldan M.S. IV. yüzyıla kadar uzanan bir zaman diliminde birçok yazar tarafindan oluşturulmuştur. Bu çalışmadan bunlar arasından yalnızca bir kısmı ele alınacak ve incelenecektir. Buna ek olarak her iki toplumun hiciv ve komedi yazarlarının eserleri de konuya ilişkin eleştirel bilgiler içermektedir. Çalışmamızda adı geçen eserlerden örnekler verilip yazarın konuya bakışı değerlendirilmeye çalışılacaktır. Yazarlar arasındaki sıralama kronolojiye göre değil konu sınıflandırmasına göre yapılmıştır. Makale Giriş ve Değerlendirme dışında iki başlık altında toplanmıştır. Bu çalışmanın sonunda adı geçen toplumların içinde sosyal statü farklılıklarına bağlı olarak yeme-içme alışkanlıklarında da farklılıklar bulunduğu, her sınıfa uygun yeme içme önerilerinin farklı yazarlar tarafından yapıldığı anlaşılııştır. İkincil olarak toplumun üst sınıfına yönelik, zengin içerikli ve pahalı yiyecekleri tanıtan ve lüks tüketimin öncüleri olan yazarlar, filozoflar ve hicivciler tarafından eleştirilmişlerdir. Son olarak doğuya olan ilginin artmasıyla birlikte Hellen ve Roma toplumlarının yemek alışkanlıklarında değişim yaşanmıştır.

Anahtar Kelimeler: Apicius, Arkhestratos, Athenaios, Cato, Columella, Yeme İçme Adetleri, Eski Batı Uygarlıkları.

ATIF: GÜVELOĞLU Ali, “Antik Çağ’’n Damak Tadı Düşkünü Yazarları” Tarih ve Gelecek

Dergisi, 5/2 (Ağustos-2019), s. (256-272)

CITE: GÜVELOĞLU Ali, “The Taste Follewer Writers of Ancient History” Journal of History and Future, 5/2 (August- 2019), pp. (256-272) 


\begin{abstract}
The purpose of this study, which is based on how people with high palatal delight in the Hellenic and Roman societies seek different tastes, is to examine the trends in the eating-drinking habits of the said civilizations, and emphasize the individuals that set such trends, if any, and their social statuses. The related information can be found in the thematic literature, written by the Hellenic and Roman authors such as Archestratos, Athenaios and Apicius in the period from III. century B.C. to the IV. century A.D. Additionally, the works of the satirists and comedy authors in both societies also include critical information thereabout. Our study includes quoted passages and examples from the works mentioned above, and assesses the authors' approach to such matters. The ancient authors are not listed chronologically, on the contrary, their list is based on the classification of the related themes. The article is grouped under two heading except prologue and conclusion. This study leads us to three basic consequences: Fist of all it is concluded that depending on their different social statutes, there are differences in the eating-drinking habits of the said societies, and the eating and drinking suggestions are made by different authors in accordance with such differences in each class. Secondly the authors addressing the upper class of the society, introducing expensive food with rich content, and being the pioneers of the luxurious consumption have been lampooned by the philosophers and satires. At the last the eating habits of the Hellenic and Roman societies have changed due to the increasing interest towards the east.
\end{abstract}

Keywords: Apicius, Arkhestratos, Athenaios, Cato, Columella, Eating and Drinking Customs, Ancient Western Civiliations.

\title{
Giriş
}

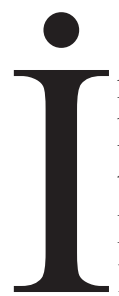

nsanlığın kadim gereksinimlerinden biri olan beslenme alışkanlıkları hem Eskiçağ'da hem de günümüzde araştırmacıların ilgisini çekmiş ve birçok çalışmaya konu olmuştur. ${ }^{1} \quad \mathrm{Bu}$ çalışmada kültürel anlamda etkileyen ve etkilenen konumlarında bulunan Hellen ve Roma toplumlarının yeme-içme alışkanlıkları bir arada ele alınacak ve çağlar içinde nasıl bir değişime uğradıkları ortaya konmaya çalışılacaktır. Adı geçen uygarlıkların yeme-içme alışkanlıklarının bir arada ele alınması çalışmayı biraz olsun karmaşık bir kurgu içinde sunmamıza neden olsa da birbirlerini ne derecede etkilendiklerini ortaya koymak açısından kaçınılmaz bir durumdur. Çünkü asıl amaç adı geçen toplumlarda tüketilen besin çeşitlerini ve yenilen yemeklerin tariflerini irdelemekten çok, damak tadı arayışlarındaki değişimi ve bu değişimi sağlayan kişi ya da olayları incelemektir. Konunun kaynakları doğal olarak Antik Çağ yazarlarının kalemlerinden çıkan edebi metinlerden oluşmaktadır. Bunlar dışında Linear A ve Linear B çivi yazılı tabletleri ile Hellence ve Latince yazıtlarda da bilgiler bulunmaktadır, ancak bu iki gruptaki yazılı bilgi yazarının belirsizliği nedeniyle kapsam dışı bırakılmıştır. Ayrıca adı geçen iki gruptaki bilgiler edebi üsluptan yoksun olarak kaleme alındığından konudan uzaklaşmamıza neden olacaktı.

1 Eskiçağdaki araştırmalar bu çalışmanın konusu olmakla birlikte, Wilkins-Harvey-Dobson'un (1995) edł itörlüğünü birlikte yaptığı Food in Antiquity, ile Andrwe Dalby’nin hazırladığg kısa adıyla Siren Feast (1996) ve D. Braund-J. Wilkins'in editölüğünü yaptığ Athenaeus and his World Reading Greek Culture in the Roman Empire, 2000 adlı kitapların kaynakça bölümleri modern araştırmaların birçoğunu göstermektedir. 


\section{Hellen Kökenli Yazarların Besin ve Damak Tadı Algısı}

Hellen dünyası tarımca zengin Sicilya ve Güney İtalya'yı keşfettikten sonra yeme içme alışkanlıklarını bir sanata dönüştürme olanağı bulmuştu, İskenderiye ve Roma gibi büyük kentler de bu sanatın yeni boyutlar kazanmasında önemli adımların atıldığı yerler olmuşlardı. ${ }^{2}$ Bunun öncesinde Eski Batı toplumunun en eski iki ozanı olan Homeros ve Hesiodos yaşadıkları dönemin damak tadı anlayışları hakkında eserlerinde dağınık bilgiler vermişlerdi. Onlara göre Hellen toplumu tarıma dayalı beslenen, ekmekle birlikte kızarmış et yiyip, şarap içen bir toplumdur. ${ }^{3}$ İlyada' da anlatılan birçok şölen gibi Akhilleus'un Odysseus ve arkadaşları için hazırlattığı yemek de k1zarmış et, ekmek ve şaraptan oluşur. Bu yemekte kahramanlar koyun, keçi ve yağlı bir domuz sırtını tercih etmiştir. Etler şişlere geçirilip odun ateşinde pişirildikten sonra doyasıya yenilmiştir. ${ }^{4}$ Destanlardaki kahramanların tercih ettiği etler arasında öküz filetolarının ve buzağının da adı geçer, ${ }^{5}$ ayrıca Hektor'un oğlu Astyanaks' ın ilikle ve koyun yağıyla beslendiği dile getirilmiştir. ${ }^{6}$ But, ciğer ve diğer sakatat çeşitlerinin de kahramanların sofralarında yer aldığı anlaşılmaktadır, ${ }^{7}$ buna karşılık Hephaistos'un yaptığı kalkandaki bir sahnede kadınlar 1rgatların yemeklerine ak un serperken resmedilmiştir. ${ }^{8}$ Homeros'un kahramanlarının sofralarında zorunlu haller dışında balık yer almaz, ${ }^{9}$ Eubulos bu duruma genel bir açıklama yapar ve kahramanların yaptığ da kaydedilmediğini, örneğin gözlerini yummadıklarını, uyumadıklarını veya yaşamsal birçok şeyi yerine getirmediklerini söyler. ${ }^{10} \mathrm{~J}$. A. Scott bu duruma farklı bir açıdan yaklaşmış ve Homeros'un Anadolu'da yaygın olan beslenme tarzına uyarak kahramanların sofrasına balık koymadığını, ozanın doğup büyüdüğü topraklarda balığın sağlıksız ve lezzetsiz görüldüğünü, zorunlu haller dışında tercih edilmediğini dile getirmiştir. ${ }^{11}$

Homeros'tan sonra Hesiodos da Hellen beslenme tarzını anlatmış, keçi, dana ve kuzu etlerinin tercih edildiğini, bunlara kabarmış ekmekle keçi sütünün eşlik ettiğini, ayrıca Byblos şarabı içildiğini dile getirmiştir. ${ }^{12}$ Hesiodos'un eserinde tahıl ve etle birlikte süt ve peynire önem verilen kırsal bir beslenme düzeni göze çarpmaktadır. Her iki ozanın eserlerinde herhangi bir lüks olgusuna rastlanmaz. Destanlarda yazılanlar halkın genelinden çok karanlık çağların soylularının tercihlerini gösterir yiyecekler olarak kahramanların sofralarında yer alırlar ve nektar ile ambrossia' dan

2 Phyllis Pray Bober, Sanat, Kültür ve Mutfak, Çev. Ü. Tansel, İstanbul, 2003, s. 96.

3 Veronika Grimm, Antik Yunan ve Roma Dünyasının Damak Tatları, Yemek: Damak Tadının Tarihi, Haz. Paul Freedman, Çev. N. Elhüseyni, İstanbul, 2008, s. 65-68.

4 Homeros, İlyada, IX. 202-221, Çev. A. Erhat, A. Kadir, İstanbul, 2004.

5 Homeros, Odysseia, XVII 180-183 Çev. A. Erhat, A. Kadir, İstanbul 2003; I. Morris ve B. Powel, A New Companion to Homer, Leiden-Newyork-Köln, 1997, p. 654.

6 Homeros, İlyada, XXII. 501.

7 Homeros, Odysseia, III. 456-466.

8 Homeros, İlyada, XVIII. 560.

9 Homeros balık avcılığı hakkında fikir sahibidir; Bk. Homeros, İlyada, XVI. 406-409; Odysseus'un erzakları bitince aç kalan arkadaşları balık tutmaya koyulmuşlardır Homeros, Odysseia, IV. 367 vd; yine aynı kahramanlar gemilerinde aç kaldıklarında balık ve kuş tutmaya koyulmuşlardır. Homeros, Odysseia, XII. 325-335; kahramanların bu balıkları yakalama ve yeme sahneeri anlatılmamıştır bk. Morris - Powel 1997, s. 603; Combellack kahramanların balık yemediği fikrine karşı çıkmış ve avladıkları kuşlarla balıkları yediklerini kanıtlamaya çalışmıştır. Bk. F. M. Combellack, Homer’s Savage Fish, The Classical Journal, 48/7, 1953, p. 260.

10 Athenaios, The Learned Banqueters, I. 25 c, translate from Greek to English by S. D. Olson, vols. I-VIII. London, 2006-2011.

11 J. A. Scot, Homeric Heroes and Fish, The Classical Journal, 12/5, 1917, p. 330.

12 Hesiodos, İşler ve Günler, 585-596, Çev. S. Eyüboğlu - A. Erhat, Ankara, 1991. 
sonra gelen en değerli yiyeceklerdir. ${ }^{13}$ Siradan insanlar bundan farklı olarak sebze, tahıl ve tahıldan yapılan lapa ile beslenmişlerdir. ${ }^{14}$ Homeros'un yaşadığı döneme ait buluntular arasında lapa ve sulu yemek yemeye uygun kase, tas ve çanakların et servisi yapılan düz tabaklardan daha fazla yer alması bu tezi destekler niteliktedir. ${ }^{15}$

Hellen ve Roma toplumlarında filozoflar da eserlerinde damak tadı tercihlerini dile getirmekten geri kalmayarak bu konunun önemine dikkat çekmek istemişlerdir. ${ }^{16}$ Sokrates yeni şekillenen bir toplumun arpa unundan yapılmış çörek ve ekmeklere peynir, zeytin, incir, nohut gibi yiyecekleri katık ${ }^{17}$ yapacağını bunların yanında lahana ve soğanla yapılan köy yemeklerini yiyeceklerini dile getirmiş, onun öğrencilerinden Ksenephon insanların büyük çoğunluğunun topraktan gelenlerle değil hayvanların verdikleriyle beslendiğini et, süt ve peynir tükettiklerini söylemiş, ${ }^{18}$ Roma'da Stoacılığın önemli temsilcilerinden olan Seneca ise aşırıya kaçan ve lüks yiyecekleri yermiş ve aşçılardan şikayetçi olmuştur. ${ }^{19}$ Hellen kökenli bir başka yazar olan Herodotos da Historiai'nin çeşitli bölümlerinde yeme içme alışkanlıklarından ve toplumların damak tadı tercihlerinden söz etmiştir. O kimi zaman Perslerin lezzetli yiyeceklerden uzak olduğunu, yiyecek doğru dürüst bir şeylere sahip olmadan yaşadıklarını söylemiş, ${ }^{20}$ kimi zaman Mısırlıların yediği kuşları, balıkları anlatmış, ${ }^{21}$ kimi zaman da insan eti yiyen toplumlardan söz ederek ${ }^{22}$ yeme içme alışkanlıkları arasındaki farklılıkları dile getirmiştir. Herodotos şölen geleneklerine de değinerek Spartalıların krallarının şölenlerde herkesin aldığının iki katı yiyecek aldığııı ve diğerlerinden önce onların içmeye başladığını dile getirerek ${ }^{23}$ yemeğin toplumsal statüyü belirlemedeki rolünü de gözler önüne sermiştir.

M.Ö. IV. yüzyıldan itibaren konuyla doğrudan ilgili eserler kaleme alınmaya başlandığı için daha net bilgiler elde edilebilmektedir. Hellenleri takip eden Romalıların da kendi toplumlarında tercih edilen yiyecekleri kaleme almakta gecikmedikleri görülmektedir. M.Ö. III. yüzyılda Hellen ve doğu kökenli aşçılarla tanışan Romalılar soslarla ve farklı malzemelerle yapılan yemeklere kendi yorumlarını katmakta gecikmemişlerdir. ${ }^{24}$

Bilinen en eski yemek kitabı yazarı olan Mithaekios'un ${ }^{25}$ eseri günümüze ulaşmamıştır. Onun ardından gelen Gela'lı Arkhestratos'un eserinden ise Athenaios'un aktardığı fragman-

13 Tanrıların ve kahramanların yiyecekleri hakkında bk. M. J. Auberger, Le Lait des Grecs: Boisson Divineou Barbare?, Dialoques d'Historie Ancienne, 27/1, 2001, p. 134; A. Dalby, Food in the Ancient World from A to Z, UK, 2003 ${ }^{\text {b }}$, p. 7.

14 H. J. Deighton, Eski Atina Yaşantısında Bir Gün, Çev. H. K. Kökten, İstanbul, 2005, s. 82; İ. Delemen, Antik Dönemde Beslenme, İstanbul, 2003, s. 5-6.

15 Delemen, 2003, s. 6.

16 L. A. Seneca, Annem Helvia'ya Teselli, X, Çev. R. Kayapınar - A. Sönmez, Ankara, 2014; Platon, Devlet, II. 372 c-d, Çev. S. Eyüboğlu ve M. A. Cimcoz, İstanbul, 1971.

17 Atinalılara göre iki çeşit yiyecek vardır birincisi ekmek ve ikincisi aralarında tuzun da olduğu ekmekle beraber yenen her türlü katık. Bk B. A. Sparkes, The Greek Kitchen, The Journal of Hellenic Studies, 1962, p. 123.

18 Ksenephon, Sokrates’ten Anılar, IV. 3. 10, Çev. C. Şentuna, Ankara, 1997.

19 Platon, Devlet, II. 372 a-b; L.A. Seneca, Ahlaki Mektuplar, XI. 87. 3, Çev. T. Uzel, Ankara, 1992.

20 Herodotos, Herodot Tarihi, I. 71, Çev. Müntekim Ökmen, İstanbul, 2002.

21 Herodotos, Herodot Tarihi, II. 77.

22 Herodotos, Herodot Tarihi, I. 123-129; III. 25; 99.

23 Herodotos, Herodot Tarihi, VI. 57.

24 A. Dalby - S. Grainger, Antikçağ Yemekleri ve Yemek Kültürü, Çev. B. Avunç. İstanbul, s. 9.

25 Platon, Gorgias, 518 b; Athenaios, The Learned Banqueters III. 112 d; VII. 282 a. 
$\operatorname{lar}^{26}$ sayesinde haberdarız. M.Ö. IV. yüzyılın sonları ile III. yüzyılın başlarında yaşadı̆̆ı bilinen Arkhestratos'un hayatı hakkında ayrıntılı bilgiye ulaşılamamıştır. ${ }^{27}$ Şiir tarzında yazılan eserin ana konusunun yemek ve damak tadı üzerine yapılan geziler olduğu bilinmekte ve eserin orijinal adının Hedyphagetica olduğu dile getirilmektedir. ${ }^{28}$ Anlaşıldığı kadarıyla Arkhestratos bir yemeğin nasıl pişirilmesi gerektiği konusundan çok yemek için gerekli malzemenin, daha doğrusu en iyi balık ya da şarabın nerede bulunabileceği konusunda bilgi vermektedir. ${ }^{29}$ Örneğin, birkaç baharat, yağ ve tuzla bir çömlek içinde pişirilen köpek balığı parçalarının Torone ${ }^{30}$ kentinden alınmasını tavsiye eder. ${ }^{31}$ Byzantion yakınlarından tutulan amiaların ${ }^{32}$ ise incir yaprağına sarılarak köze gömülmesini ve pişirirken peynir gibi şeylere bulaştırılmaması gerektiğini hatırlatır. Ancak onun için en önemlisi balığın Byzantion yakınlarında bir yerlerde tutulmuş olmasıdır. Hellespontos'tan ne kadar uzaklaşılırsa balığın tadı o denli bozulur der yazar. ${ }^{33}$ Kent balık çeşitliliği ve lezzeti bakımından yalnızca Arkhestratos'un değil birçok Antik Çağ yazarının ilgisini çekmiştir. ${ }^{34}$ Aralarında Atina'nın da olduğu birçok kente tuzlanmış veya tütsülenmiş balık satmasıyla ünlü olan Byzantion uskumru, palamut gibi balıklar açısından oldukça zengindir. ${ }^{35}$ Yazar bir başka metinde akrep balığının Thasos kentinden alınmasını ve çok büyük olanlardan kaçınılmasını tavsiye eder, ${ }^{36}$ ancak fragman burada sonlanmaktadır ve Arkhestratos'un bu balık hakkındaki pişirme önerisi ne yazık ki kayıptır.

Arkhestratos, Kartaca yakınlarında tutulan çipuranın lezzetli, Byzantion yakınlarında tutulanın da irice olacağından söz ederek bölgeler arası farklılıklara dikkat çekmiştir. Yazar bu balığı peynir, kimyon, tuz ve yağa buladıktan sonra iyi bir kil fırına asarak pişirmenin en iyi yol olduğunu da söylemiş ve konuyu bu şekilde sonlandırmıştır. ${ }^{37}$ Ainos'un midyesi, Abydos'un istiridyeleri, Parion'un yengeci ve Mytilene'nin deniztarağı, yazar tarafindan övülmüsstür, bununla birlikte hepsinin bir arada ve sınırsız miktarda bulunabileceği yer olan Ambrakia diğer kentlerden daha fazla övgü almıştır. ${ }^{38}$ Messenia yakınlarında tutulan yılanbalığını başka yerlerde tutulanlardan üstün sayar Arkhestratos, ayrıca ona göre ikram edilmesi durumunda yılanbalığı bir şölende en fazla

26 Fragmanlar ve açıklamalar için bk. J. Wilkins ve S. Hill, Fragments From the Life of Luxery, Devon, 2011, p. 33 vd.; ayrica bk. S. D. Olson ve A. Sens, Archestratos of Gela; Greek Culture and Cusine in the Fourth Century BCE; Text, Translation and Commentary, London, 2000, p. 13 vd.

27 Arkhestratos'un eserini ne zaman ve nerede kaleme aldığı hakkında ayrıntılı bilgi için bk. A. Dalby, Archestratos Where and When, Food in Antiquity, Eds. J. Wilkins et al. Exeter, 2003a , p. 402-404; ayrica bk. Olson ve Sens 2000, p. XIX.

28 S. P. Pauline ve E. Degani, Archestratus, RE I, Leiden et al, 2002, p. 983. Athenaios, The Learned Banqueters, VII. 278 d.

Bk. Dalby ve Grainger, 2001, s. 33.

Arkhestratos, Fragments, 24.

Amiaları oluşturan palamut ve torikler boğazın akıntısından dolayı hız kesmiş, bu nedenle boğazçevresinde oltayla bile kolayca yakalanabilmişlerdir bk. P. Bursa, Antikçağda Anadolu'da Balık ve Balıkçılık, Yayınlanmamış Doktora Tezi. İstanbul Üniversitesi, 2007, s. 91.

Bober 2003, s. 97; Antik Çăgda balık tüketimi konusunda ayrıntılı bilgi için bk. N. Purcell, Eating Fish The Paraadoxes of Seafood, Food in Antiquity, Eds. J. Wilkins et al. Exeter, 2003, p. 135 vd.

O. Tekin, Eskiçăğ' da İstanbul'da Balık ve Balıkçılık, İstanbul, 2010, s. 14 -18.

P. Bursa, Antikçağda Anadolu'da Balık ve Balıkçılık, İstanbul, 2010, s. 14; M. Arslan, İstanbul'un Antikçă̆ Tarihi, İstanbul, 2010, s. 407 vd.

Arkhestratos, Fragments From the Life of Luxery, 29, Translation by. J. Wilkins ve S. Hill, Devon, 2011. Athenaios, The Learned Banqueters, VII. 320 f; fragman hakkındaki yorum için bk Wilkins ve Hill 2011, p. 65.

Arkhestratos, Fragments, 14.

Arkhestratos, Fragments, 7. 
keyif veren yiyeceklerdendir. Kopa ve Strimonia yakınlarında tutulan yılan balıkları Messenia'da tutulanlar kadar güzel olmasa da onlarla yarışacak kadar iyidir. ${ }^{39}$ Arkhestratos birçok balık için övgü dolu sözler söylemişse de Ambrakia'daki domuz balığı için oldukça iddialı sözler kullanmış, “Ambrakia'ya gider de domuz balı̆̆ bulursanız ă̆ırlı̆̆ınca altın değerinde olsa bile sakın kaçırmayın $^{40 "}$ " diyerek bu balığı okuyucularına önermiştir. Yüksek fiyata satılan bir başka balıktan da Seneca aracılığıyla haberdar oluyoruz. Onun anlatısına göre imparator Tiberius kendisine gelen irice bir balığı satılmak üzere pazara gönderir ve Apicius veya P. Octavius'tan birinin satın alacağını iddia eder. Söylediği şey gerçekleşir, P. Octavius beş bin sestertius ödeyerek bu balığı satın alır ve imparatora hediye eder. ${ }^{41} \mathrm{Bu}$ iki örnek bir balık için ne kadar yüksek fiyatların ödenebileceğini ve damak tadı arayışlarının nerelere kadar varabileceğini göstermesi açısından önemlidir.

Arkhestratos'un balıklardan başka şaraplar ${ }^{42}$ hakkında da fikirlerini dile getirip öneriler yaptığı görülmektedir. Şaraplar arasında Fenike'den gelen Byblos şarabı ile Lesbos adasının şarabı Arkhestratos'un en sevdikleridir. Byblos şarabının tadı daha kırılgan olduğundan Lesbos şarabını tercih etmiştir. ${ }^{43}$ Gela'lı gezgin yemek tarifleri ve malzeme seçiminden başka masa düzeni ${ }^{44}$ hakkında da öneriler yapar; buna ek olarak üç, dört veya en fazla beş kişiyle yemek yenmesi gerektiğini, aksi takdirde yemekleri öğüten bir ordudan başka bir şeye sahip olunmayacağını söyler. ${ }^{45}$ Hellenlerin şölenlerde konuklarına ve masa düzenine verdikleri önem bilinmektedir. ${ }^{46}$ Balıkları ve ana malzemeleri ayrıntılı bir şekilde anlatan Arkhestratos'un peynir çeşitlerini çoğunlukla sos yaparken ya da balığı kızartmadan önce kaplamak için kullandığı görülmektedir. ${ }^{47}$ Bir yemek masasının önemli unsurlarından olan ekmeklerin en iyisini Lidyalı ya da Fenikelilerin yaptığını dile getirmiştir, ${ }^{48}$ Athenaios ise onun Kappadokialıları tanımadığı için bu konuda yanıldığını söylüyor ${ }^{49}$

Arkhestratos'un yalın bir damak tadı anlayışına sahip olduğu anlaşıllıyor. Yiyecekleri baharata bulamanın ve güçlü çeşniler katmanın bir yararı olmayacağı üzerinde önemle durmuştur. ${ }^{50}$ Arkhestratos'un amacının gastronomik deneyim ve bilgi edinmek olduğu ve bu bilgileri elde edebilmek için çeşitli geziler yaptığı kendi satırlarından anlaşılmaktadır. ${ }^{51}$ M.Ö. III. yüzyıla gelindi-

39 Athenaios, The Learned Banqueters VII. 298 e; Arkhestratos, Fragments, 10.

40 Athenaios, The Learned Banqueters VII. 305 e-f.

41 Seneca, Ahlaki Mektuplar, 95. 42.

42 Bk. Arkhestratos, Fragments, 3; 23; 48; 59; ayrica bk. Athenaios, The Learned Banqueters X. 457 c; VII. 310 c-e; VII. 314 e; III. 101 e.

43 Arkhestratos, Fragments, 59. 17; Athenaios, The Learned Banqueters, III. 101 e.

44 Hellen ve Roma toplumunda yemek uzanılarak yenirdi. Her iki toplumun yemek masası ve düzeni hakkında görsel bilgi için bk. K. M. D. Dunbabin, The Roman Banquet: Images of Convivality, UK, 2003, p. 11-36.

45 Arkhestratos, Fragments,. 4; Açıklamalar için bk. Olson ve Sense 2000, p. 20.

46 Klasik bir Hellen şöleninde masa ve konukların oturma düzeni hakkında bk. P. S. Pantel, La Cité au Banquet: Histoire des Repas Publics dans les Cités Grecques, Rome, 1997, p. 17 vd.

47 Arkhestratos, Fragments, 13; 31; 36; 48; 57; Ayrica bk. Athenaios, The Learned Banqueters, VII. 320 b, VII. 328 a; VII. 321 c; VII. 314 e; IX. 399 d.

48 Arkhestratos, Fragments, 6.

49 Athenaios, The Learned Banqueters, III. 112 b; ayrıca bk. Wilkins ve Hill 2011, p. 42; Olson ve Sense 2000, p. 37.

50 Dalby ve Grainger 2001, s. 63.

51 Arkhestratos, Fragments, 2; Athenaios, The Learned Banqueters, IX. 383b; Açıklamalar için bk. Olson ve Sense 2000, p. 15-16. A. Dalby metin üzerinde yaptığı incelemenin ardından Arkhestratos'un verdiği bilgilerle dönemin gerçeklerinin örtüştüğünü ve yazarın bu gezileri bizzat gerçekleştirmiş olduğunu söylemektedir. Bk. Dalby, 2003ª , p. 405. 
ğinde eseri geniş bir okuyucu kitlesine ulaşmış yazarın gezileri sırasında ziyaret ettiği Roma'nın güney bölgelerinde de tanınmaya başlamıştır. ${ }^{52}$

Güzel yiyecek bulabilmek için uzun seyahatlere çıkabiliyor olması ve gerektiğinde bir balık için ağırlığınca altın harcamayı göze alması onun varlıklı olduğunu göstermektedir. Bu nedenle Arkhestratos'tan kalan tarifler ve öneriler çoğunlukla üst sınıf zenginlere uygundur. Ayrıca henüz doğudan gelen baharatlara yabancı olması ve soslardan uzak durması da eserini Büyük İskenderin doğu seferinden önce tamamladığı kanısını uyandırmaktadır.

\section{Romalı Yazarların Damak Tadı Algısı}

Misır'ın Naukratis kentinde doğan Athenaios (Ölümü ca. 190/192) 15 kitaptan oluşan ${ }^{53}$ Deipnosophistai (= Bilgelerin Sofrası/Şöleni) adlı eserinde aralarında Gramerci Aemilianus Maurus, Kynik Filozof Cynulcus, tıpçı Galenos, müzisyen Masurius, Tyreli gramerci Ulpianus, gibi ünlü ve bilgili kişilerin bulunduğu 29 kişinin Roma' da konuk olduğu hayali yemek sahnesini anlatmaktadır. ${ }^{54}$ Konuklar bu hayali şölenlerde bir arada bulunup yemek yemiş ve sanattan yemeğe, spordan cinselliğe kadar birçok konuda hayali sohbet etmişlerdir. Eser kanonik anlatım biçiminde kurgulanmış, böylece metin zenginleştirilmiştir. ${ }^{55}$ Athenaios Homeros'tan kendi dönemine kadarki yazın birikimini örnekler vererek kullanmış, bu sayede kaybolmuş bazı eserlerden haberdar olmamızı sağlamıştır. ${ }^{56}$

Yukarıda adı geçen ünlülerin katıldığı şölenleri Larensis adlı bir kişi düzenlemekte ve onların yemekte sergilediği tutumlar bu kişi tarafından anlatılmaktadır. Eserdeki Larensis evinde dünyanın en geniş kütüphanesine sahip olan bilgili bir kişi olarak görünmektedir. Şölenlere katılan kişilere türlü yemekler ikram edildikten sonra konuklar kütüphanede çeşitli araştırmalar yaparlar. ${ }^{57}$ Olson, Larensis' in gerçek bir kişi olduğunu söylerken onun Athenaios'un arkadaşı ve patronu olabileceğini öne sürer. ${ }^{58}$ Roma magistratlarından olan Larensis lüks yaşam biçiminin Roma'yı esir alması, kölelerin say1s1 ${ }^{59}$ ve evlilikle ${ }^{60}$ ilgili konularda yorum yapmaktan geri durmamıştır.

Athenaios'un aktardığı ilgi çekici şölenler arasında Lefkaslı Philoksenos'un ${ }^{61}$ bir çömlek dolusu yılan balığı, ballı karidesler, yufkalar içinde yavru kuşlar, firında pişirilmiş ton balıkları ikram ettiği şöleni ayrı bir yer tutar. Yemek ve içkiye iyice doyulunca hizmetkârlar masaları temizler, parfümler ve havlular dağıtır, bundan sonra yemeğin ikinci kısmına geçilir (secundae mensae). ${ }^{62}$

52 Wilkins ve Hill 2011, p. 11-13.

53 John Wilkins Athenaios'un eserinin günümüze eksiklerke ulaştığını, aslında toplamda 30 kitaptan oluşş ması gerektiğini dile getirmektedir. Bk. J. Wilkins, Athenaeus the Navigator, The Journal of Hellenic Studies, 128, 2008, p. 132.

54 E. Bowie, Athenaeus, RE II, Leiden et al, 2002, p. 240.

55 Wilkins, 2008, p. 133 vd.

56 L. J. Lloyd, Athenaeus, The Cambridge Dictionary of Classical Civilizations, Cambridge, 2009, p. 100; ayrica bk. Bober, 2003, s. 96.

57 J. Wilkins, Land and Sea: Italy and the Mediterranean in the Roman Discourse of Dining, The American Journal of Philology, 124, 2003, p. 369.

58 S. D. Olson, The Learned Banqueters, Cambridge ve London, 2006, p. viii.

59 Athenaios, The Learned Banqueters, VI. 272 e.

60 Athenaios, The Learned Banqueters, XIII. 558 e.

61 Lefkaslı Philoksenos hakkında; Athenaios, The Learned Banqueters, I. 5 b, d-e; 6 d; IV. 146 f; 147 e.

62 Secundae mensae =İkinci masa olarak adlandırılan yiyecekler tatlı ve meyvelerden oluşur ve gustatio (ikramlar) ile primae mensae (et ağırlıklı yemekler)den sonra sunulurdu. Bu masaya geçmeden önce 
$\mathrm{Bu}$ bölümde tatlı hamurlar, gevrek gözlemeler, ballı kekler ile susamlı şekerlemeler ikram edilir. ${ }^{63}$ Konuyu ilgi çekici kılan şey Philoksenus'un kimliğindeki belirsizlik ve ondan geriye başka bir literatür kalmamış olmasıdır. Athenaios'un anlatısı dikkate alınırsa Phileoksenos'un varlıklı ve gelişkin damak tadı anlayışına sahip bir kişi olduğu anlaşılır. Ancak en önemlisi onun anlatısındaki lezzet düşkünlüğüdür. Sunduğu sofra yaşadığı döneme göre hayli zengin ve gösterişlidir. Yine Athenaeios'un eserinde rastladığımız bir başka Philoxenos (Kytheralı) hem damağına hem de boğazına düşkündür. O şölenlerinde çok çeşitli lüks yemek sunmanın yanında keyif ehlidir zürafanınki gibi bir boğazı olsun ister ki lokmaları yutarken uzun uzadıya tadına varabilsin. Anlatılanlara göre Kytheralının ölümü de boğazına düşkünlüğünden kaynaklanmış. Syrakusa'dan aldığı büyükçe bir ahtapotun kafası hariç tamamını bir oturuşta yiyen ve bundan dolayı mide ağrısı çekemeye başlayan Philoxenos'a doktor öleceğini bildirince işlerini yoluna koyup vasiyetini hazırlayan damak tadı düşkünü ahtapotun geri kalan kısımlarını yemeye koyulmuş. ${ }^{64}$ Damak tadı düşkünlüğünün erken temsilcilerinden biri olan Kytheralı Philexenox'un ölümüyle ilgili olarak anlatılanlar onun bu alışkanlığını karalamak amacı taşıyor olabilir.

Yazarın aktardıkları arasında yer alan kral Antiokhos'un şöleni savurganlık temaları içermektedir. Anlatılanlara göre onun her gün düzenlediği şölenlere birçok kişi katılır yediklerinin yanı sıra canlı ve pişmiş hayvanlardan alabildikleri kadar alır, yanlarındaki develere yükleyebildikleri kadar içecek yükler ve götürürlermiş, ayrıca altın eşyalar ve gümüş vazolarla beraber aldıkları köleler de cabası ${ }^{65}$ Sicilyalı tiran Dionysios da kalabalık şölenler vermesiyle ünlüydü, onun evinde otuz döşek yerleştirilmiş bir yemek salonu bulunuyordu ki bu sayı klasik bir şölen için gerçekten fazlayd1. ${ }^{66}$

Mos maiorum fikrinin savunucusu, Hellen kültürünün ve lüks yaşam tarzının Roma'ya girmesine sonuna kadar karşı çıkmış ${ }^{67}$ Romalı devlet adamı Marcus Porcius Cato (M.Ö. 234 - 149) De Agricultura adlı eserinde aslen çiftlik yönetimi üzerinde dursa da zaman zaman rüstik yemek tariflerine de yer vermiştir. ${ }^{68}$ De Agricultura' da çeşitli yemek tariflerinden çok yiyecek maddelerini korumaya yönelik saklama koşulları dile getirilmiştir. Tariflerden birinde yeşil zeytinleri daha uzun süre saklamak için çekirdeklerinin çıkarılıp doğrandıktan sonra yağ, sirke, kişniş, kimyon, rezene, sedef otu ve naneyle birlikte bir toprak kaba konması tavsiye edilir. ${ }^{69}$ Yazar üzüm suyunu bir yıl boyunca taze saklamak için onu bir amphoraya koyarak toprak altında otuz gün bekletmek gerektiğini söyler. ${ }^{70}$

Yaşlı Cato'nun eserinde yer verdiği tarifler malzeme ölçülerini de içermesi bakımından önem taşımaktadır. Buğday unu ve peynir karışımıyla yapılan Libum bunlardan ilkidir. ${ }^{71}$ İkincisi aynı malzemelerle yapılan ve altına yaprak konularak pişirilen keklerdir. ${ }^{72}$ Kırsal damak tadının temsilcisi olarak sayılabilecek bir diğer tarif olan placenta un, irmik, peynir karışımıyla yapılan

masalar köleler tarafından temizlenir ve konuklara kokular dağıtılırdı. Bk. Grimm, 2008, s. 88 vd.

63

64

65

Athenaios, The Learned Banqueters, I. 5 b-f.

Athenaios, The Learned Banqueters, VIII. 341 a-c.

Athenaios, The Learned Banqueters, XII. 540 b.

Athenaios, The Learned Banqueters, XII. 541 c.

Plutarkhos, Hayatlar; Aristides-Cato Maior, XXVI. 1. 1-3, Çev., A. Sina, Ankara, 2014.

W. Kierdorf, Cato, RE IV, Leiden et al, 2003, p. 21.

Cato, On Agriculture, CXIX, translation by W. D Hooper ve H. B. Ash, London, 1935.

Cato, On Agriculture, CXX.

Cato, On Agriculture, LXXV.

Cato, On Agriculture, CXXI. 
yufkaların arasına zeytinyağ 1 ve bal sürülerek elde edilen hem ekmek hem de tatlı yerine yenilebilecek bir yiyecektir. ${ }^{73}$ Cato'nun verdiği tariflerin hacim olarak büyük oldukları görülmektedir. Ancak bu tür peynirli ekmeklerin kalabalık dinsel ayinler sırasında tüketildiği göz önünde tutulursa onu daha anlaşılır olacaktır. Cato'nun tarifleri arasında incir, zeytin, zeytinyağı ve şarapla ilgili kısımlar Akdeniz dünyasının vazgeçilmez ürünlerini yetiştirme, kullanma ve saklama koşullarıyla ilgili bilgiler içerir. ${ }^{74}$

Yaşlı Cato'ya ait ilgi çekici tariflerden biri de globi adlı tatlı tarifidir. Peynir ve irmik karışımlarının yuvarlak toplar halinde kızgın yağda kızartılıp bala bulanarak servis edildiği bu tatlı, günümüz Türkiye'sindeki peynir tatlısı ile lokma tatlısının birleşmiş halini andırmaktadır. Örneklerden Yaşlı Cato'nun incelikli ve çeşitli yemek tarifleri peşinden koşmadığı, daha ziyade gündelik hayatta işine yarayacak, hazırlanması kolay ve sıradan yiyecekleri kaydetmeyi tercih ettiği anlaşılmaktadır. Rüstik yaşam tarzını öven Cato ${ }^{75}$ yeme-içme konusunda da bu tercihini sürdürmüştür. Çiftçilik üzerine kitap yazan bir başka Romalı olan Columella da Cato'nunkilere benzer peynirli ve unlu tarifler vermiştir. ${ }^{76} \mathrm{Bu}$ iki yazarın Roma'nın kırsal damak tadı temsilcisi oldukları ve halka yönelik tarifleri kaydettikleri söylenebilir. Zenginler sofralarını çeşitli lüks yiyecekler, pahalı balıklar, beyaz ekmek ve etle süslerken orta sınıf ve fakirler protein ihtiyaçlarını çeşitli baklagillerle karşılamıştır. ${ }^{77} \mathrm{Bu}$ durum Cato ve Columella'nın eserlerinin değerini anlaşı1ır kılmaktadır.

Eskiçağ yemek kitapları arsında en fazla üne ve en fazla bilinmeze sahip olan Apicius'un kısaca De re Coquinaria, uzun olarak De Opsoniis et condimentis sive de re culinaria libri decem adıyla bilinen yemek kitabıdır. Bu kitap muhtemelen M.S. IV. yüzyılda yaşayan Caelius Apicius tarafından yazılmış ve imparator Tiberius döneminde yaşamış olan damak tadı düşkünü Marcus Gavius Apicius'un tarifleriyle (Apician) ${ }^{78}$ birleştirilerek yayımlanmıştır. ${ }^{79}$ A. Dalby'ye göre M. G. Apicius M.Ö. 90'lı yıllarda yaşamış, adı Apicius olan başka bir damak tadı düşkününden esinlenerek bu ismi almıştır. ${ }^{80}$ Athenaios'ta adı geçen diğer bir Apicius, imparator Traianus döneminde yaşamıştır. Anlatıya göre Traianus Parthia'da seferdeyken canı taze yengeç istediğinde denizden günlerce yolluk uzaklıkta bulunduğundan bu isteği yerine getirilememiş, ancak Apicius kendi bulduğu bir yöntemle yengeçleri paketleyerek imparatora taze olarak sunulmasını sağlamıştır. ${ }^{81}$ Juvenalis'e göre Apicius bir şahıs isminden çok damak tadı düşkünü olan zenginlere verilen

73 Cato, On Agriculture, LXXVI.

74 İncirle ilgili tarifler için bk. Cato, On Agriculture, XXI, zeytin ve zeytinyağı için bk. XVII, XXIII, XXV, XXVII, LXXVII, LXIX CXVII; üzüm ve şarap için bk. XIX, XXI, XLIII.

Plutarkhos, Hayatlar; Aristides-Cato Maior, 1 vd.

76 Columella, On Agriculture, XII. 59. 1- 2, translation by E. S. Forster-E. H. Heffner, London 1955.

77 Hellen ve Roma sofralarında baklagilllerin yeri ve önemi hakkında bk. B. F. Hamilton, Legumes in Ancient Greece and Rome: Food, Medicine, or Poison?, The Journal of the American School of Classical Studies at Athens, 68/3, 1999, s. 373 vd; Baklagillerle yapılan çorba için bk. E. S. P. Ricotti, Dining as a Roman Emperor, Roma, 1999, s. 36.

78 Metinde “Apician” adıyla bilinen 7 tarifin Tiberius dönemindeki Apicius’tan geldiği düşünülmeke tedir. C. Grocock ve S. Grainger, Apicius: A Critical Edition with an Introduction and English Translation, Great Britain, 2006, s. 38; Tarifler için bk. Apicius, De re Coquinaira, IV. 1. 2; IV. 2. 14; IV. 3. 3; V. 4. 2; VII. 4. 2; VIII. 7. 6.

79 Pauline 2002, 983-984; ayrıca bk. H. L. Million, An Old Roman Cookbook, The Classical Journal, 21, 1926, p. 443; Bober, 2003, s. 177.

80 A. Dalby, Apicius, The Cambridge Dictionary of Classical Civilizations, Cambridge, 2009, p. 57; W. Ramsay, Apicius, A Dictionary of Greek and Roman Biography and Mythology I, 2007, USA, p. 225.

81 Apicius, De re Coquinaira, I. 7 a. 
genel bir addır. ${ }^{82}$ Tertullianus'a göre aşçılar ve yemek okulları onun adıyla anılmıştır, ${ }^{83}$ bununla birlikte yemek tariflerini toparlayan ve aşçılıkta ün salmış kişiler kendilerini Apicius ismiyle özdeşleştirmiş ve edindikleri yemek tariflerini bir şekilde bu isimle bağdaştırarak kitaba girmesini sağlamış olabilirler. Kendilerinden önceki yemek kitabı yazarlarının isimlerini veren Athenaios ve Columella'nın Apicius'tan bir yazar olarak söz etmediklerini dile getiren Grocock ve Grainger onun kendi döneminde bir yemek kitabı yazarı olarak bilinmediğini, bunun yanı sıra gerçek olamayacak kadar kötü bir karakter olduğunu dile getirmişlerdir. ${ }^{84}$

Yukarıda adı geçen dört Apicius’tan ikincisi, yani imparator Tiberius döneminde yaşamış olan damak tadı düşkünü Marcus Gavius Apicius oburluğu, aç gözlülüğü ve lükse düşkünlüğüyle tanınmıştır. Onun bu özellikleriyle ilgili olarak anlatılan öyküler ilgi çekicidir. Bir tanesine göre; Minturnae'de yazlığındayken Libya kıyılarında iri karidesler bulunduğunu duymuş ve bir gün bile kaybetmeden bu karideslerin peşine yelken açmıştır. Ancak hedef noktaya vardığında kıyıda bekleyen yerli balıkçıların kendisine sunduğu karidesleri yeterince iri bulmayınca gemiden inmeden dümenciye İtalya'ya geri dönmesini emretmiştir. ${ }^{85}$ Seneca'nın aktardığı bir diğer öyküye göre açgözlü Apicius elinde kalan mal varlığını hesaplamış ve anca 1 milyon sestertius'u kaldığını görünce bu parayla doğru dürüst bir şeyler yiyemeyeceğini söyleyip zehir içerek intihar etmiştir. ${ }^{86}$

On kitaptan oluşan De re Coquinaria'nın içeriği Athenaios'un eserinden farklı olarak tamamen yiyecek ve içeceklerle ilgilidir. Kitaptaki yemek tariflerinin teknik bilgiler içermesi yazarlarının uzmanlar ya da aşçılardan oluştuğu fikrini uyandırmaktadır. ${ }^{87}$ Apicius'un eserinde tarifleri oluşturan malzemelerin miktarları belirtilmemiş ve pişirme sırası hakkında bilgi verilmemiştir.

De re Coquinaria'nın ilk kitabında incelikli bir damağa hitap edebilecek baharatlarla, güllerle ve diğer otlarla yapılmış rayihalı şaraplardan söz edilir. ${ }^{88}$ Aynı kitapta liquamenden limona, şaraptan yaban mersinine kadar birçok malzemenin nasıl en iyi şekilde korunacağı bilgisi yer almaktadır. ${ }^{89}$ Et yemekleri ve çeşitli sosların yer aldığı ikinci kitapta bir çeşit kan, çeşitli sebzeler, yumurta sarısı, çam fistığı, öğütülmüş biber liquamen ${ }^{90}$ ve şarapla yapılan botellum sic facies adlı sos farklı malzemelerin bir arada sunulması bakımından ilgi çekicidir. ${ }^{91}$ Apicius'un eserinden Roma mutfağında sosların zenginleşmeye başladığı açıkça görülmektedir. Onun sebze yemeklerinde tuz yerine liquamen veya oenagarum ${ }^{92}$ kullanılmıştır. ${ }^{93}$ Adı geçen malzemelerin bolca tuz içermesi ve bunun yanında çeşitli otlarla rayihalandırılmış olması yemeğe farklı bir tat katmış olsa gerektir.

82 Juvenalis, Juvenal and Persis, IV. 22-23, translation by S. M. Braund, London, 2004; ayrıntılı bilgi için bk. E. Gowers, The Loaded Table, UK \& Newyork, 2003, p. 188 vd.

83 Tertullianus, Apology. De Spectaculis Minucius Felix: Octavianus, III. 6, tanslation by T. R. Glover, London, 1931.

84 Grocock ve Grainger, 2006, p. 55.

85 Athenaios, The Learned Banqueters, I. 7 a-c.

86 Seneca, Annem Helvia'ya Teselli, X.

87 Grocock ve Grainger 2006, 13.

88 Bk. Apicius, De re Coquinaira, I. 1-4.

89 Apicius, De re Coquinaira, I. 13-22.

90 Liquamen veya garum; küçük balıkların iç organları ve baş kısımlarının çeşitli otlarla bir araya gete irilip deniz suyuyla karıştırılması yoluyla elde edilen ve Romalıların yemeklerinde sıkça kullandığı bir tür sostur. Bk. Dalby ve Grainger 2001, s. 15-16.

91 Apicius, De re Coquinaira, II. 3. 2.

92 Oenagarum; garum ya da liquamen adıyla bilinen balık sosunun şarap ve zeytinyağıyla çeşnilendirilmiş halidir. Tarifi için bk. Grocock ve Grainger 2006, s. 355. 
Onun önerileri arasında nane ve liquamenle birlikte servis edilen kavundan ${ }^{94}$ pişmiş salatalıklara, ${ }^{95}$ zeytinyağ1 ve sirke ile servis edilen haşlanmış şalgamdan ${ }^{96}$ kızarmış havuçlara ${ }^{97}$ kadar çeşitli meyve ve sebzeler yer almaktadır. Bu tür hafif atıştırmalıklar pişmiş yemeklerin yanında veya sonrasında damakta tazelik hissi uyandırmak için kullanılmış olabilir.

Apicius'un tariflerinden pultes tractogalatae kurutulmuş hamur parçalarının bal ve süt karışımında pişirilmesiyle hazırlanan bir çorbadır. ${ }^{98}$ Bu tarif et, liquamen, ithal baharatlar ${ }^{99}$ gibi pahalı malzemeler içermemesi nedeniyle Apicius'ta rastlayabileceğimiz en sade tariflerden biridir ve Apicius'un eserinde alt ve orta gelir gurubundaki insanlar için de tarifler yer aldığının göstergesidir. ${ }^{100}$ Kırmızı etin ağırlıklı olduğu De re Coquinaria'da çeşitli soslarla çeşnilendirilen tavuk yemekleri de önerilmiştir. ${ }^{101}$ Apicius'un tarifleri arasında domuz eti, beyin, çiğ yumurta, çam fistığ 1 ile doldurulduktan sonra biber, silphium, liquamen zencefil baharatlarla kaplanan domuz işkembesi hem et, hem baharat, hem de sakatat içeriği ile ilgi çekicidir. Apicius'un tarifleri arasında bu tür karışımların sıkça yer aldığı görülmektedir. O et ve sakatat türlerini birleştirip doğunun aromatik baharatlarıyla çeşnilendirmeyi seviyor ve bu tür tariflere sıkça başvuruyordu. ${ }^{102}$ Yukarıdaki örneklere bakarak Apicius'la birlikte Romalıların damak tadının değişime uğradığını ve doğunun baharatlarının Roma mutfağına hakim olmaya başladığını söylemek mümkündür.

Eserin deniz ürünlerine ayrılmış olan IX. kitabında salsum sine salso ismiyle yer alan tarif, malzeme listesinde deniz ürünü olmayan bir balık yemeğine aittir. ${ }^{103}$ Bu tarifteki ustalık; yani balık görünümünde ciğerler hazırlama işi Grocock ve Grainger'in tariflerin uzmanlar tarafından hazırlandığı yönündeki tezini doğrular niteliktedir. ${ }^{104}$

Arkhestratos'un eserinde rastladığımız yemekler ve pişirme yöntemleri Hellenistik Dönem öncesi Akdeniz dünyasına ait yemekleri temsil ederken Apicius'a atfedilen kitapta yer alan tarifler değişime uğramış ve Akdenizlilikten çok doğulu unsurlar taşımaya başlamıştır. ${ }^{105}$ Özellikle bol baharatlı ve soslu olarak hazırlanan yemekler Roma ve Akdeniz dünyasında yenidirler. Bu yüzden Stoacı filozof Seneca, Apicius'u ve onun temsil ettiği aşırı savurgan yemek yeme alışkanlıkla-

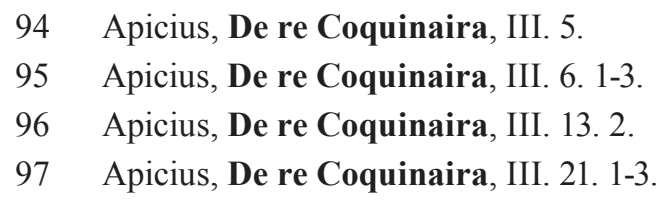

98 Apicius, De re Coquinaira, V. 1. 3; Cato ve Apicius'un tariflerini verdiği placenta ve tracta günümüz tarhanasıyla benzerlik göstermektedir, ancak aynı şey değildir. Hill - Bryer tarhananın bir Pers yemeği olduğunu ve Pers dilinde trachanás olduğunu dile getirirler bk. S. Hill ve A. Bryer, Byzantine Porridge Tracta, Trachanas and Tarhana, Food in Antiquity, Eds. J. Wilkins et al, Exeter, 2003, p. 47-49. Konu henüz netlike kazanmış değildir. Ancak günümüz tarhanası ile Cato ve Apicius'un tarifleri arasında malzeme bakımından benzerlik, uygulama açısından da farklılık olduğu anlaşılmaktadır.

99 Bk. Garnsey, 1999, p. 37.

100 Garnsey Apicius'un kitabında fakirlere uygun hiçbir tarifin yer almadığını söylemektedir. Bk. P. Garnsey, Food and Society in Classical Antiquity, UK, 1999, p. 115.

101 Apicius'un eserinde tavuk etiyle yapılan 15 tarif yer almaktadır bk. Apicius, De re Coquinaira, VI. 8. 1-15.

102 Doldurulmuş domuz işkembesi için bk. Apicius, De re Coquinaira, VII. 7. 1; Apicius’un sakatat tarifleri için bk. Apicius, De re Coquinaira, VII. 7. 1-10.

103 Apicius, De re Coquinaira, IX. 10. 10. Tarifte çeşitli baharatlar ve liquamenle çeşnilendirilen ciğerler balık şeklinde hazırlanmıştır.

104 Grocock ve Grainger, 2006, p. 13.

105 Garnsey, 1999, p. 15 vd.; ayrica bk. Bober, 2003, s. 169-171. 
rını eleştirmiştir. ${ }^{106}$ Klasik bir Antik Çağ yemeğinde üç veya dört baharat ya da ot kullanılırken Apicius'un yemeklerinde on baharat bulunabiliyordu. ${ }^{107}$

Eserin X. kitabında deniz ürünleri için hazırlanan 35 farklı sos tarifi yer alır. Malzeme olarak en çok biber, nane, kimyon, kişniş tohumu, kereviz tohumu, bal, sirke, Suriye sumağı, kuru ayva, soğan, yumurta sarıs1, kuru üzüm şarab1 vb. tercih edilmiştir. ${ }^{108}$ Veronika Grimm'e göre Apicius'un kitabı birçok yazarın farklı zamanlarda katkılar sağlamasıyla bir araya gelmiş ortak bir üründür. Kitapta hem zengin hem de orta sınıf aileler için uygun tarifler yer almaktadır. Grimm ayrıca Romalı aşçıların gıdaları terbiye etmek yoluyla yeni tat arayışları içine girdiğini, Apicius'un bolca $\operatorname{sos}^{109}$ tarifi içeren kitabının bu yüzden sevildiğini ve popüler konuma geldiğini dile getirmektedir. ${ }^{110}$

Zenginliği sayesinde damak tadı arayışlarını pahalı şölenlerle birleştiren Lucius Licinius Lucullus (M.Ö. ca.114-57), Sulla'nın subayı olarak III. Mithradates savaşları sırasında'111 Asya'da görev yaptığı sırada büyük bir servete sahip olmuştur. ${ }^{112}$ Damak tadına düşkünlüğüyle tanınan bu subay İtalya'yı kiraz ağacıyla tanıştıran kişi olarak bilinir. ${ }^{13}$ Aslında İtalya' da kirazın yakın akrabası olan vişne önceden beri biliniyordu. Lucullus'un Kerasus (Bugünkü Giresun) civarından alarak Roma'ya götürdüğü fidanlar vişnenin tatlı türü olan kirazdır. ${ }^{114}$ Plutarkhos Lucullus'un hayatını iki perdeli bir Antik Çağ komedyasına benzetmiş, ilk kısmının devlet görevleri ve askeri kamplarda geçtiğini, ikincisinin ise şölenlerle ve eğlencelerle dolu olduğunu dile getirmiştir. ${ }^{15}$ Öyle ki Lucullus'un sofrası yalnızca yemek çeşitliliğiyle değil, aynı zamanda mor renkli minderleri, değerli taşlarla süslü kadehleri ve eğlenceli içeriğiyle de dikkat çekmiştir. ${ }^{116}$ Plutarkhos'a ait bir anlatıda Lucullus'un Pompeius ile Cicero'yu evinde bir akşam yemeğinde ağırladığı ve 50.000 drahmi tutarındaki yemeği çok kısa bir sürede hazırlattığ 1 anlatılmaktadır. ${ }^{17}$ Her ne kadar boğazına düşkün biri olarak anılsa, adı eğlenceli ve uzun süren şölenlerle bilinse de Lucullus'un masasında gerçekten neler bulunduğu hakkında bir bilgiye ulaşılamamıştır. ${ }^{118}$ Lucullus'un Antik Çağ damak tadı arayışına görsel bir boyut kazandırdığı, tattığı yemek çeşitliliğinden çok evindeki yemek oda-

106 Seneca, Annem Helvia’ya Teselli, X; L. A. Seneca, Ahlaki Mektuplar, 95. 42.

107 Dalby ve Grainger, 2001, s. 11.

108 Apicius, De re Coquinaira, X. 1. 1-7.

109 J. Solomon, The Apician Sauce: Ius Apicianum, Food in Antiquity, Eds. J. Wilkins et al, Exeter, 2003, p.119 vd.

110 Grimm, 2008, s. 94.

111 Lucullus'un Üçüncü Mitradates Savaşı sırasındaki faaliyetleri ve devamında Armenia üzerine yaptığ1 sefer hakkında ayrıntılı bilgi için bk. M. Arslan, Mithradates Eupator VI: Roma'nın Büyük Düşmanı, İstanbul, 2007, s. 340 vd. Ayrica bk. A. Keaveney, Lucullus a Life, London \& Newyork, 1992, p. 75.

112 Lucullus'un edindiği servet hakkında bk. Plutarkhos, Kimon-Lucullus, IV. 1, Çev. A. Sina, Ankara, 2013; ayrica bk. W. Wolfgang, L. Lucullus, RE VII, Leiden et al, 2005, p. 530.

113 Plinius, Natural History, XV. 102, translation by H. Rackham, London, 1945; Deipnosophistai'de Greklerin övünmeye başladığı bir noktada Larensis söz alır ve “...siz Grekler her şeyi bulduğunuzu ve isim verdiğinizi sanırsınız, ama bizim general Lucullus’un Pontos’un Kerasus şehrinden kiraz fidanlarını ilk olarak getirip İtalya'da diktiğinden ve Cerasus şehrinden esinlenerek ona ad verdiğinden habersizsiniz" diyerek kirazın İtalya’ya yaptığı yolculuğu kısaca özetler. Bk. Athenaios, The Learned Banqueters, II. $50 \mathrm{f}$.

114 Vişnenin İtalya'daki serüveni hakkında bak Plinius, Natural History, XV. 102; ayrıca bk. Keaveney, 1992, p. 145 ve A. Uhri, Boğaz Derdi, İstanbul, 2011, s. 228.

115 Plutarkhos, Kimon-Lucullus, XXXIX. 1.

116 Plutarkhos, Kimon-Lucullus, XL. 1.

117 Plutarkhos, Kimon-Lucullus, XLI. 4-5.

118 Keaveney, 1992, p. 146. 
ları ve masasındaki süslü takımlarla anıldığı söylenebilir.

Lucullus zengin ve kalabalık sofralarda şölen düzenleme konusunda yalnız değildir, aynı zamanda en iyi olanı da değildir. Roma imparatorlarından Nero kendisi sabahlara kadar süren şölenler düzenlemiş, arkadaşlarını da pahalı şölenler düzenlemeye zorlamıştır. ${ }^{119}$ İmparator bununla da kalmayıp bilinen son silphium ${ }^{120}$ demetini Kyrene'den getirterek tüketmiştir. ${ }^{121}$ Bir başka Roma imparatoru Vitellius onuruna düzenlenen şölenlerin her biri en azından dört yüz bin sestertiusa mal oluyordu. Kardeşinin düzenlediği bir şölende ise ender bulunan balıklardan iki bin, kuşlardan da yedi bin tane hazırlandığı söylenir. ${ }^{122}$ Anlaşılan Romalılar Hellenlerden öğrendikleri incelikli yemek yeme işini art coquinariaya çevirmişlerdir. ${ }^{123}$ Buna rağmen Romalıların büyük bir çoğunluğu hayatlarında hiç şölene katılmamış ve nadiren et yemiştir. ${ }^{124}$

\section{Değerlendirme}

Hellen toplumunun en eski iki ozanı tarafından belirlenen ideal beslenme tarzı kızarmış et, ekmek ve şaraptan oluşur. Bu beslenme tarzı kahramanlara özgü olduğundan tanrıların yiyeceği olan ambrosia ve nektar'dan sonra gelen en değerli yiyeceklerden oluşması doğaldır. Onların sofralarında etin en değerli kabul edilen bölümleri yer alırken, sebze, süt veya tahıldan söz edilmemiştir. Ancak bu durum destanlara özeldir, gerçekte halk sulu yemek ve lapa ağırlıklı bir beslenme tarzı sürdürmüştür.

Homeros ve Hesiodos'tan sonra aralarında Sokrates ve Platon'un da bulunduğu bir dizi filozof yalın beslenme tarzını övmüş ve ögütlemiştir. Onların bu ögütlerinin hızlı bir şekilde terk edildiği görülmektedir. Gela'lı Arkhestratos'un damak tadı arayışı içinde uzun süreli ve masraflı yolculuklar yapmayı göze alması Hellen damak tadı arayışı içinde bir sıçramadır. Çünkü kendisi eserini kaleme almadan yaklaşık elli - yetmiş yıl önce yeni kurulan düzende yaşayacak insanlara ekmek, çörek ve köy yemeklerinden başka bir şey önermeyen Sokrates'in önerileriyle Arkhestratos'un önerileri arasında önemli bir fark vardır. Biri sofraya hiç et koymazken diğeri balık ve şarap uğruna Pers donanmaları tarafından ablukaya alınmış Akdeniz ve Karadeniz kıyılarının önemli bir kesimini gezmiş ve deneyimlerini not etmişti. Hellen toplumundaki bu yeni arayışlar Atina'da doğmadı, Arkhestratos Sicilya adasında dünyaya gelmiş, Syrakusa ve Güney İtalya'yı da gezip deneyimlerini Hellence olarak kaydetmişti.

Eserini Arkhestratos'tan uzun bir süre sonra kaleme alan Athenaeios Misır'ın Naukratis kentinde dünyaya gelmiş, Hellence yazarak Hellen ve Atina dünyasına hitap etmiştir. Onun eseri yalnızca yemek tariflerinden ve lüks tüketimden söz etmez, aynı zamanda bilgelerin sofrasıdır ve kendinden önceki birçok edebiyat eserinden alıntılar yapar. Böylece damak tadı zenginliği ile kültürel zenginliği bir araya getirmiştir.

119 Nero'nun arkadaşlarına düzenlettiği iki şölen hakkında bk G. T. Suetonius, 12 Caesar'ın Yaşamı, (Nero) XXVII, Çev. Ü. Fafo Telatar ve G. Özaktürk. Ankara, 2008; ayrıca bk J. M. Higgins, Cena Rosaria Cena Mitellita: A Note on Suetonius Nero 27. 3, The American Journal of Philology, 106/1, 1985, p. 117.

120 Silphium Kyrene'de yetişen ve şifalı olduğuna inanılan aromatik bir bitkidir. Hellenler ve Romalılar tarafından yemeklerde ve liquamen yapımında kullanılmıştır. Bk. Dalby ve Grainger, 2001, s. 17-19.

121 Plinius, Natural History, XIX. 39.

122 Suetonius, 12 Caesar'ın Yaşamı, (Vitellius) XIII.

123 T. Long, Barbarians in Greek Comedy, USA, 1986, p. 69 vd.

124 Gowers, 2003, p. 2. 
Hellen damak tadı deneyiminde ilkin soylulara ve kahramanlara yönelik alışkanlıklar kaydedilmiş, ardından yoksul halk sınıfının ihtiyaçları ve olanakları doğrultusunda öneriler yapılmış, Hellenistik dönemle birlikte varlıklı kesimin damağına ve kesesine uygun yemek tarifleri kayıt altına alınmıştır.

Roma'da damak tadı tercihleri üzerine fikirlerini ilk belirtenler kırsal yemekleri kayıt altına almışlardı. Cato, Columella ve Varro gibi kırsal hayatın temsilcileri halkın kolayca ulaşabileceği unlu, bakliyatlı tarifleri kaleme alarak Roma'da damak tadı araştırmalarını başlatmışlardır. Onlar eserlerini kendi dillerinde kaleme almışlar ve Roma'nın içinden çıkmışlardır. Aynı dönemde Romalıların bir kısmının Arkhestratos’un eserlerinden haberdar olduğu da bilinmektedir.

Roma'da yönetimin Cumhuriyetten imparatorluğa geçmesiyle birlikte daha zengin ve kısmen Hellenleşmiş bir yaşam tarzı sürülmeye başlanmış, bunun etkisiyle Romalılar da lüks yiyeceklerin peşine düşerek bu yönde eserler vermeye başlamışlardır. Daha ilk imparatorlardan Tiberius'un döneminden itibaren adı anılmaya başlanan M. G. Apicius Romalıların sofralarına doğulu unsurlar taşıyarak onları bol baharatlı ve soslu yemeklerle tanıştırmıştır. Onun adının efsaneleşmesi bazı imparatorların kendilerine Apicius'u örnek almalarına neden olmuş, Nero ve Vitellius gibi isimler hem yedikleri yiyeceklerde uç noktalara ulaşmış, hem de yemek salonlarının süslenmesini ve yemekte kullanılan eşyaların her türlü lüksle buluşmasını sağlamışlardır.

Hellen ve Roma toplumlarında sosyal statü farklılıklarına bağlı olarak yeme-içme alışkanlıklarında da farklılıklar bulunduğu, her sınıfa uygun yeme içme önerilerinin farklı yazarlar tarafından yapıldığı anlaşılmıştır. Örneğin zengin ve orta sınıfa uygun yiyecekler Arkhestratos ve Athenaios'un eserlerinde yer alırken Cato, Varro ve Columella gibi yazarlar daha çok alt gelir grubundaki kişilere yönelik tarifleri kaydetmiş̧lerdir. Apicius'un De re Coquinaria'sında her üç sınıfa da hitap edecek farklı tarifler yel almıştır. Bu sınıflar arasında en alt gelir grubuna hitap eden tariflerin sayıca az olduğu fark edilmiştir. Bunun nedenini anlayabilmek için bu sınıfın tükettiği yiyecek çeşitlerini ve okuma yazma oranını incelemek gereklidir.

Toplumun üst sınıfına yönelik, zengin içerikli ve pahalı yiyecekleri tanıtan ve lüks tüketimin öncüleri olan yazarların yemek tarifi üretme ve kaydetme konusunda oldukça verimli oldukları gözlemlenmiştir. Bir yemeği lezzetli ve gösterişli yapmak için masraftan kaçmadıkları ve servetlerini bu uğurda tükettikleri için filozoflar ve hicivciler tarafından yerilmişlerdir. Özellikle Apicius'un lüks tüketim merakı Seneca tarafından eleştirilmiştir. Ayrıca Horatius ve Petronius gibi yazarlar buradan hareketle obur, gözü doymaz kişilikler yaratarak bunlar üzerinden lüks tüketim alışkanlıklarını yermişlerdir.

Doğuya olan ilginin artmasına ve kronolojiye bağlı olarak Hellen ve Roma toplumlarının yemek alışkanlıklarında değişim yaşanmıştır. Özellikle Sicilya ve Güney İtalya'nın Romalıların eline geçmesiyle birlikte bu topraklarda yaşayan Hellenler doğuya yönelmişlerdir. Arkhestratos'un Akdeniz limanlarında gerçekleştirdiği geziler batı uygarlıklarının doğunun tatlarıyla tanışmasına aracılık etmiştir. Bu limanlarda bulunan doğu kökenli baharatlar yavaş yavaş batıya doğru aktarılmaya başlanmıştır. Hellenlerin ardından Romalıların doğu topraklarını ele geçirmesi onların da doğrudan doğruya doğu kökenli yiyecekleri ve malları kullanarak şölenler düzenlemesiyle sonuçlanmıştır. Lucullus'un mor renkli minderleri ile Kerasus'tan getirttiği kiraz fidanları gözle görünen örneklerdendir.

Kısacası; Hellen ve Roma toplumlarında damak tadı algılarının değişimi ve yönetimi olaylar ve kişiler ekseninde gerçekleşmiş̧tir. Hellen toplumu damak tadını anlayışını oluşturan ve geliştiren öncüleri Sicilya ve Mısır gibi ana topraklarının dışından ithal etmiş ve onların öncülüğünde yürümüş, Romalılar ise kırsaldan lükse doğru uzanan damak tadı arayışlarını kendi topraklarından çı- 
kan yazarlar aracılığıyla yakalamıştır. Elbette Apicius'un kimliğindeki belirsizlik ve Hellenlerden etkilenme olasılıkları da göz ardı edilmemelidir.

\section{Bibliyografya}

A. Keaveney, Lucullus a Life, London \& Newyork, 1992.

Ahmet, Uhri, Boğaz Derdi, İstanbul, 2011.

Andrew, Dalby ve S. Grainger, Antikçă̆ Yemekleri ve Yemek Kültürü Çev. B. Avunç, İstanbul, 2001.

Andrew, Dalby, Apicius, The Cambridge Dictionary of Classical Civilizations, 2009, Cambridge, p. 56-57.

Andrew, Dalby, Archestratos Where and When, Food in Antiquity, Eds. J. Wilkins et al. Exeter, 2003ª , p. 400-412.

Andrew, Dalby, Food in the Ancient World from A to Z, UK, $2003^{\text {b. }}$

Andrew, Dalby, Siren Feast: A History of Food and Gastronomy in Greece, London ve New York, 1996.

Apicius, De re Coquinaria: A Critical Edition with an Introduction and English

Translation. Translation by. C. Grocock ve S. Grainger, Great Britain, 2006.

Arkhestratos, Fragments From the Life of Luxery, Translation, J. Wilkins ve S. Hill, Devon, 2011.

Athenaios, The Learned Banqueters, translation by S. D. Olson, vols. I-VIII. London, 2006-2011.

B. A. Sparkes, The Greek Kitchen, The Journal of Hellenic Studies, 1962, p. 121-137.

B. F. Hamilton, Legumes in Ancient Greece and Rome: Food, Medicine, or Poison?, The Journal of the American School of Classical Studies at Athens, 68/3, 1999, p. 371-385.

C. Grocock ve S. Grainger, Apicius: A Critical Edition with an Introduction and English Translation, Great Britain, 2006.

Columella, On Agriculture, translation by E. S. Forster-E. H. Heffner, London 1955.

David, Braund ve John, Wilkins, (Eds.), Athenaeus and his World; Reading Greek

Culture in the Roman Empire. UK, 2000.

E. Bowie, Athenaeus, RE II, 2002, Leiden et al, p. 240-242.

E. S. P. Ricotti, Dining as a Roman Emperor, Roma, 1999.

Emily, Gowers, The Loaded Table, UK \& Newyork, 2003.

F. M. Combellack, Homer's Savage Fish, The Classical Journal, 48/7, 1953, p. 257-261.

G. T. Suetonius, 12 Caesar'ın Yaşamı (Nero; Vitellius.) Çev. Ü. Fafo Telatar-G.

Özaktürk, Ankara, 2008.

H. L. Million, An Old Roman Cookbook, The Classical Journal, 21, 1926, 443-450.

Herodotos, Herodot Tarihi, Çev. Müntekim Ökmen, İstanbul, 2002. 
Hesiodos, İşler ve Günler, Çev. S. Eyüboğlu ve A. Erhat, Ankara, 1991.

Hillary, J. Deighton, Eski Atina Yaşantısında Bir Gün, Çev. H. K. Kökten, İstanbul, 2005.

Homeros, İlyada. Çev. A. Erhat ve A. Kadir, İstanbul, 2004.

Homeros, Odysseia, Çev. A. Erhat ve A. Kadir, İstanbul, 2003.

I. Morris - B. Powel, A New Companion to Homer, Leiden-Newyork-Köln, 1997.

İnci, Delemen, Antik Dönemde Beslenme, İstanbul, 2003.

J. A. Scot, Homeric Heroes and Fish, The Classical Journal, 12/5, 1917, p. 328-330.

J. M. Higgins, Cena Rosaria Cena Mitellita: A Note on Suetonius Nero 27. 3, The American Journal of Philology, 106/1, 1985, p. 116-118.

J. Solomon, The Apician Sauce: Ius Apicianum, Food in Antiquity, Eds. J. Wilkins et al. Exeter, 2003, 115-131.

John, Wilkins - M. Harvey ve M. Dobson, (Eds.) Food in Antiquity, Exeter, 2003.

John, Wilkins ve S. Hill, Archestratus: Fragments from the Life of Luxury; Translatin, Commentary and Introduction, Great Britain, 2011.

John, Wilkins, Athenaeus the Navigator, The Journal of Hellenic Studies, 128, 2008, p. 132-152.

John, Wilkins, Land and Sea: Italy and the Mediterranean in the Roman Discourse of

Dining, The American Journal of Philology, 124, 2003, p. 359-375.

Juvenalis, Juvenal and Persis, translation by S. M. Braund, London, 2004.

Kethrine, M. D. Dunbabin, The Roman Banquet: Images of Convivality, UK, 2003.

Ksenephon, Sokrates’ten Anılar, Çev. C. Şentuna, Ankara, 1997.

L. A. Seneca, Ahlaki Mektuplar, Çev. T. Uzel, Ankara, 1992.

L. A. Seneca, Annem Helvia'ya Teselli, Çev. R. Kayapınar ve A. Sönmez, Ankara, 2014.

L. J. Lloyd, Athenaeus, The Cambridge Dictionary of Classical Civilizations, Cambridge, 2009, p. 99-100.

M. J. Auberger, Le Lait des Grecs: Boisson Divine ou Barbare?, Dialoques d'Historie Ancienne, 27/1, 2001, p. 131-157.

Marcus Porcius, Cato, On Agriculture, translation by W. D Hooper ve H. B. Ash, London 1935.

Murat, Arslan, İstanbul'un Antikçağ Tarihi, İstanbul, 2010.

Murat, Arslan, Mithradates Eupator VI: Roma'nın Büyük Düşmanı, İstanbul, 2007.

N. Purcell, Eating Fish The Paraadoxes of Seafood, Food in Antiquity, Eds. J. Wilkins et al. Exeter, 2003, p. 132-149.

Oğuz, Tekin, Eskiçă̆g' da İstanbul'da Balık ve Balıkçılık, İstanbul, 2010.

P. S. Pantel, La Cité au Banquet: Histoire des Repas Publics dans les Cités Grecques, Rome, 1997.

Peter, Garnsey, Food and Society in Classical Antiquity, UK, 1999. 
Phyllis Pray Bober, Sanat, Kültür ve Mutfak, Çev. Ülkün Tansel, İstanbul, 2003.

Pınar, Bursa, Antikçağda Anadolu’da Balık ve Balıkçılık, İstanbul, 2010.

Pınar, Bursa, Antikçağda Anadolu'da Balık ve Balıkçılık, Yayınlanmamış Doktora Tezi, İstanbul Üniversitesi, 2007.

Platon, Devlet, Çev. S. Eyüboğlu ve M. A. Cimcoz, İstanbul, 1971.

Plinius, Pliny Natural History, translation by H. Rackham, London, 1945.

Plutarkhos, Hayatlar; Aristides-Cato Maior, Çev. A. Sina, Ankara, 2014.

Plutarkhos, Hayatlar; Kimon-Lucullus, Çev. A. Sina, Ankara, 2013.

S. D. Olson ve A. Sens, Archestratos of Gela; Greek Culture and Cusine in the Fourth Century BCE; Text, Translation and Commentary, London, 2000.

S. D. Olson, The Learned Banqueters, London, 2006.

S. P. Pauline ve E. Degani, Archestratus, RE I, Leiden et al, 2002, p. 983.

Shaun, Hill ve Anthony, Bryer, Byzantine Porridge Tracta, Trachanas and Tarhana, Food in Antiquity, Eds. J. Wilkins et al. Exeter, 2003, p. 44-53.

T. Long, Barbarians in Greek Comedy, USA, 1986.

Tertullianus, Apology; De Spectaculis Minucius Felix: Octavianus, translation by T. R. Glover, London, 1931.

Veronika, Grimm, Antik Yunan ve Roma Dünyasının Damak Tatları, Yemek; Damak

Tadının Tarihi, Ed. Paul Freedman, İstanbul, 2008 s. 65-99.

W. Kierdorf, Cato, RE IV, Leiden et al, 2003, p. 20-23.

W. Ramsay, Apicius, A Dictionary of Greek and Roman Biography and Mythology I, USA, 2007, p. 225-226.

W. Wolfgang, L. Lucullus, RE VII, Leiden et al, p. 2. 